\title{
Structure Modeling Of Improvement In The Quality Of Welfare Service And Research Trends On Welfare Industry In Japan
}

\author{
Ayako Oura, Waseda University, Japan \\ Manabu Yamaji, Waseda University, Japan \\ Atsushi Ogihara, Waseda University, Japan
}

\begin{abstract}
In Japan, the quality of service provided in elder care facilities is drawing special attention after the enforcement of the Long-term Care Insurance Act in 2000. This study is aimed at proposing a structure model on improvement in quality of welfare service and clearing a research trend on welfare industry in Japan by systematic review. At first, Key words regarding to the quality of welfare service were taken by related papers. And then we discussed those key words using KJ method and developed the structure model composed of four areas and three-layer structure. Second, a literature search was exhaustively performed with 12 keywords on Cinii and Google Scholar databases for papers published between 1991 and 2010. From the papers returned by the search, the 63 original papers were examined. This study showed that the staff's care burden and nursing consciousness were featured themes. On the other hand, there were few researches as a customer satisfaction or information management. In addition, these researches only considered short-term effects.
\end{abstract}

Keywords: Quality of Service; Research Trends; Structure Model

\section{INTRODUCTION}

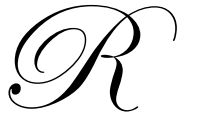

ecently, Japan has been facing serious concerns of a rapidly aging population and a very low birthrate, changing family structure, and the need to promote the independence and social participation of persons with disabilities. Further, the demand for welfare service in Japan has been rising every year. The growth rate in the population of people aged 65 years or older keeps rising. In 2015, the rate is expected to reach $20 \%$, which will soon be followed by a full-blown aging society [1].

In recent years, with changes in society and economy, corporate structures and services have been diversified, and approaches to the quality of service have been given increasing attention. The idea of Total Quality Management (TQM) that started with manufacturing has been gradually extended to the service industry. Academically, discussion of this idea has centered on the improvement of awareness of users' rights and the stable management of facilities. In the welfare industry, the enforcement of the Long-term Care Insurance Act in 2000 called special attention to the quality of service provided in elder care facilities.

However, this involves several problems, one of which is that there is a lack of sufficient scientific validation in literatures about the quality of service in elder care facilities. In the welfare industry, which provides nursing services, the approach to improvethe quality of service poses a serious challenge to the development of the welfare industry. 


\section{DEVELOPMENT OF THE STRUCTURE MODELON IMPROVEMENT IN THE QUALITY OF WELFARE SERVICE}

This study is aimed at carrying out a systematic scientific review of papers examining the quality of service in elder care facilities in Japan; the study also involves an attempt to systematically arrange the scientific evidence on the quality of service in elder care facilities.

First, we created a structure model on improvement in quality of welfare service shown at Figure 1. TQM is intended to provide employee satisfaction (ES), customer satisfaction (CS), and social satisfaction (SS). We classified the components of improving the quality of service in welfare into four groups: information management system, facilities environment/employment environment, care skill/welfare service, and management personnel and information.

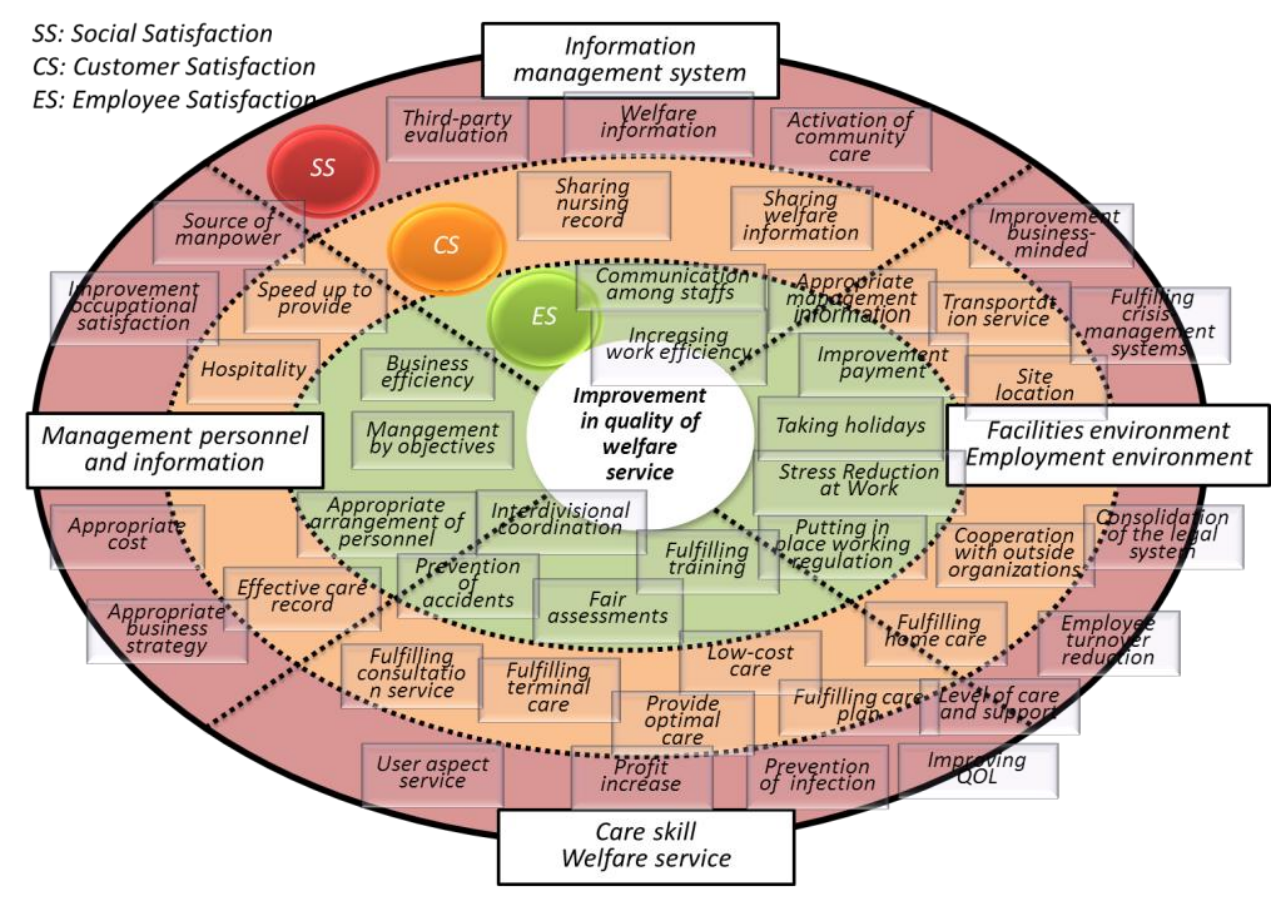

Figure 1. Structure model on improvement in quality of welfare service

Their components were taken by related papers [2-4]. And then we put in them each area on the model.

\section{RESEARCH METHOD}

A search was performed on Cinii and Google Scholar databases for papers published between January 1, 1999 and July 31, 2010. The retrieval period is June 20 through June 26, 2010, during which we searched the papers $[5,6]$. Twelve combinations of retrieval wards were shown in Table 1.

For this purpose, it is important to develop a new methodology that will enable us to create a strategic service model that will anticipate customer requirements and supply those services at the appropriate time, and also assess the effectiveness of the service model (fig. 1). 
Table 1. Retrieval words and dates

\begin{tabular}{|l|c|c|}
\hline \multicolumn{1}{|c|}{$\begin{array}{c}\text { Combination of retrieval words } \\
\text { (in Japanese) }\end{array}$} & Cinii & Google Scholar \\
\cline { 2 - 3 } & 20-Jun & 20-Jun \\
\hline Welfare \& management & 20-Jun & 20-Jun \\
\hline Nursing \& management & 20-Jun \\
\hline Nursing \& quality & 20-Jun & 20-Jun \\
\hline Welfare \& quality & 22-Jun & 22-Jun \\
\hline Welfare \& ISO & 22-Jun & 22-Jun \\
\hline Nursing \& ISO & 25-Jun \\
\hline Welfare \& standardization & 25-Jun & 25-Jun \\
\hline Nursing \& standardization & 26-Jun & 26-Jun \\
\hline Welfare \& information & 26-Jun & 26-Jun \\
\hline Nursing \& information & 26-Jun & 26-Jun \\
\hline Welfare \& human resource & 26-Jun & 26-Jun \\
\hline Nursing \& human resource & & \\
\hline
\end{tabular}

We added each total and the overlapping papers were removed. Moreover, papers pertaining to child welfare were removed.

As a result, the total papers including overlapping were 132,269 , removing overlapping were 1144 , and of which 63 were the original papers. We showed the secular change of the papers, and classified them by the objective, theme, and the method.

\section{RESULTS}

We obtained the following results. Table 2 shows the retrieval word and hits. Figure 2 shows a process of screening all papers.

Table 2. Retrieval word and hits

\begin{tabular}{|l|c|c|c|c|}
\hline \multicolumn{1}{|c|}{ Cinii } & Original Papers & Total & Original Papers \\
\hline $\begin{array}{c}\text { Combination of retrieval } \\
\text { words(in Japanese) }\end{array}$ & Total & 4 & 12,900 & 299 \\
\hline Welfare \& management & 2,818 & 0 & 5,130 & 114 \\
\hline Nursing \& management & 1,824 & 18 & 8,100 & 288 \\
\hline Nursing \& quality & 1,633 & 80 & 21,400 & 986 \\
\hline Welfare \& quality & 3,920 & 1 & 859 & 40 \\
\hline Welfare \& ISO & 155 & 1 & 225 & 9 \\
\hline Nursing \& ISO & 80 & 4 & 4,350 & 300 \\
\hline Welfare \& standardization & 166 & 0 & 1,270 & 86 \\
\hline Nursing \& standardization & 77 & 72 & 29,200 & 937 \\
\hline Welfare \& information & 8,999 & 5 & 12,000 & 437 \\
\hline Nursing \& information & 4,214 & 1 & 6,990 & 213 \\
\hline Welfare \& human resource & 940 & 1 & 3,180 & 70 \\
\hline Nursing \& human resource & 1,830 & & & \\
\hline
\end{tabular}

The most number of the combinations of searching wards were "welfare\& information" on Cinii and Google Scholar.

\subsection{Secular change of the number of papers}

As a result of the paper search, it was found that the total number of papers is 1,144, and of which 152 are the original papers. Figure 3 shows the secular change in the number of papers. It shows the total number of papers, the original papers, the research papers and others. 


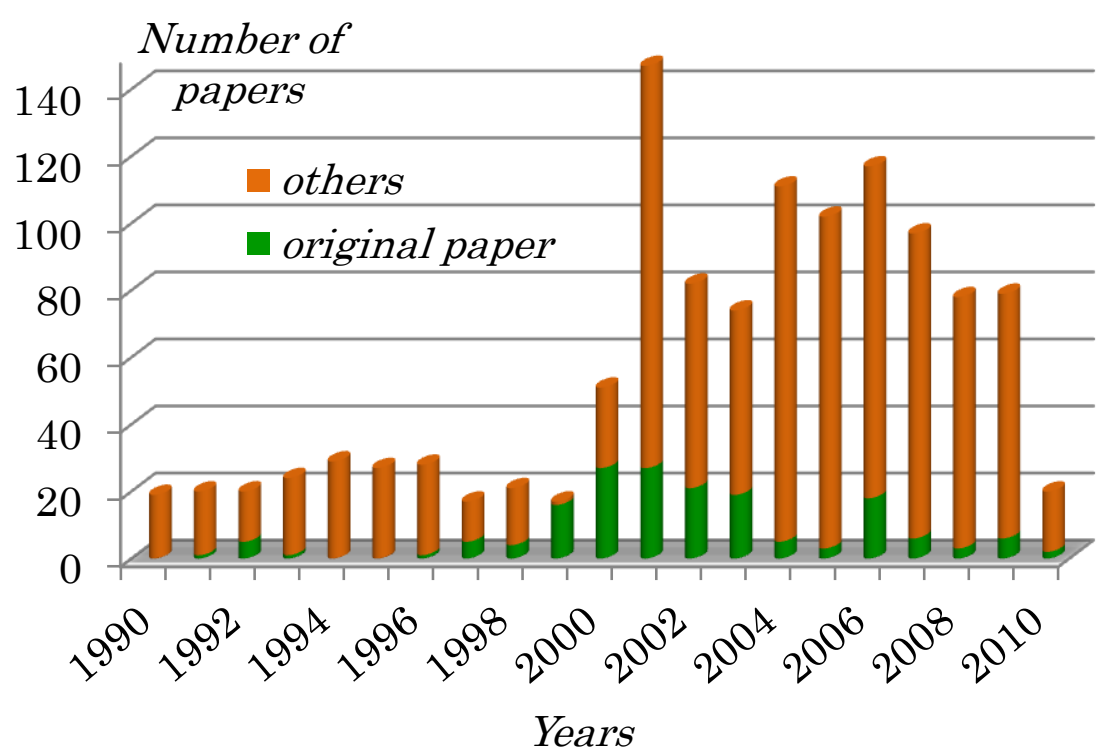

Figure 2. Secular change of the number of papers

Figure 2 show that academic interest in the welfare industry reached a peak in the beginning of 2000. The nursing insurance system was also implemented in 2000, and the welfare industry was reviewed in 2005 [7]. For this reason, related papers increased by 2001 and 2006.

\subsection{Base Attribute of Paper Search}

Totally, the 63 original papers were classified by subjective, objective, theme and method using the title and content summary (Table 3 ) 
Volume 3, Number 2

Table 3.63 of original papers

\begin{tabular}{|c|c|c|c|c|c|c|}
\hline \multirow[b]{2}{*}{ Author } & \multirow{2}{*}{$\begin{array}{l}\text { Bibliographic } \\
\text { information }\end{array}$} & \multirow[b]{2}{*}{ Subject } & \multirow[b]{2}{*}{ Methods } & \multicolumn{3}{|c|}{ Classification } \\
\hline & & & & Methods & $\begin{array}{l}\text { Sub } \\
\text {-ject }\end{array}$ & Theme \\
\hline Yumi, T(1991)[9] & $\begin{array}{l}\text { The journal of Juntendo } \\
\text { Medical College of } \\
\text { Nursing2, 30-40. }\end{array}$ & $\begin{array}{l}\text { Patients and their families who receive visiting } \\
\text { nursing from the hospitals and clinics in certain } \\
\text { limited areas. }\end{array}$ & The fact-finding survey giving questionnaires & $\begin{array}{l}\text { Questionnaire } \\
\text { research }\end{array}$ & Both & Home care \\
\hline $\begin{array}{l}\text { Eguchi, } N \\
\text { (1997)[10] }\end{array}$ & $\begin{array}{l}\text { Memoirs of Ashikaga } \\
\text { Junior College17(1), } 65 \text { - } \\
72 .\end{array}$ & Nursing staff at facilities for homes. & $\begin{array}{l}\text { Giving questionnaires to find the relationship } \\
\text { between the basic attributes of stresses and stressors, } \\
\text { as well as the effects of psychological stress } \\
\text { responses and the observation of the process. }\end{array}$ & $\begin{array}{l}\text { Questionnaire } \\
\text { research }\end{array}$ & Staff & $\begin{array}{l}\text { Caregiver } \\
\text { awareness }\end{array}$ \\
\hline $\begin{array}{l}\text { Eguchi, } N \\
\text { (1998)[11] }\end{array}$ & $\begin{array}{l}\text { Memoirs of Ashikaga } \\
\text { Junior College 18(1), } \\
\text { 103-108. }\end{array}$ & $\begin{array}{l}\text { A stratified multi-level randomization method from } \\
\text { new and middle class matrons who were actually } \\
\text { involved innursing }\end{array}$ & $\begin{array}{l}\text { The survey items included health status and } \\
\text { subjective recognition of stress. }\end{array}$ & $\begin{array}{l}\text { Questionnaire } \\
\text { research }\end{array}$ & Staff & $\begin{array}{l}\text { Caregiver } \\
\text { awareness }\end{array}$ \\
\hline $\begin{array}{l}\text { Iwamoto, } S \\
(1998)[12]\end{array}$ & $\begin{array}{l}\text { Bulletin of the School of } \\
\text { Nursing, Yamaguchi } \\
\text { Prefectural University 2, } \\
\text { 13-21. }\end{array}$ & $\begin{array}{l}\text { Living in "H City" of Yamaguchi Prefecture was } \\
\text { conducted. This city is } 10 \text { years ahead of the national } \\
\text { averages in terms of the proportion of aged citizens in } \\
\text { the general population. }\end{array}$ & $\begin{array}{l}\text { Understanding the elderly population's knowledge } \\
\text { and understanding of such reforms interviews of } \\
\text { elderly citizens. }\end{array}$ & $\begin{array}{l}\text { Interview } \\
\text { research }\end{array}$ & User & Governance \\
\hline $\begin{array}{l}\text { Ogata, M., Doi, } M \\
\text { (1999)[13] }\end{array}$ & $\begin{array}{l}\text { Kawasaki journal of } \\
\text { medical welfare } 9(2), \\
155-161 \text {. }\end{array}$ & Four special nursing homes. & $\begin{array}{l}\text { Complaints of fatigue in } 38 \text { care givers working day } \\
\text { and night shifts in the special nursing home for the } \\
\text { aged were surveyed. }\end{array}$ & $\begin{array}{l}\text { Questionnaire } \\
\text { research }\end{array}$ & Staff & $\begin{array}{l}\text { Caregiver } \\
\text { awareness }\end{array}$ \\
\hline $\begin{array}{l}\text { Takeda, I } \\
\text { (1999)[14] }\end{array}$ & $\begin{array}{l}\text { Kawasaki journal of } \\
\text { medical welfare } 9(2), \\
\text { 169-176. }\end{array}$ & $\begin{array}{l}1 \text { city } 6 \text { town in Okayama, two welfare institutions for } \\
\text { elderly people. }\end{array}$ & $\begin{array}{l}\text { Creating a reliable and valid QOL index based on an } \\
\text { investigation of the public care insurance system and } \\
\text { a questionnaire investigation concerning QOL. }\end{array}$ & $\begin{array}{l}\text { Questionnaire } \\
\text { research }\end{array}$ & User & $\begin{array}{l}\text { Care } \\
\text { assessment }\end{array}$ \\
\hline $\begin{array}{l}\text { Eguchi, } N ., \\
\text { Ishiguro, } K ., \\
\text { Tomizawa, } \\
\text { (1999)[15] }\end{array}$ & $\begin{array}{l}\text { Memoirs of Ashikaga } \\
\text { Junior College 19(1), } \\
\text { 55-61. }\end{array}$ & $\begin{array}{l}\text { By observing such parameters as the qualifications of } \\
\text { case managers, professional requirements, activities } \\
\text { of "ON-LOK" in the United States and through a } \\
\text { comparison of the management of home nursing } \\
\text { systems in Japan. }\end{array}$ & $\begin{array}{l}\text { Investigating the manner of activities of home nursing } \\
\text { stations in Japan by comparing the heath care } \\
\text { systems of the United States and Japan. }\end{array}$ & $\begin{array}{l}\text { Related } \\
\text { document } \\
\text { research }\end{array}$ & Staff & Home care \\
\hline $\begin{array}{l}\text { Higashi, T., } \\
\text { Uchiyama, K., } \\
\text { Kusano, T., } \\
\text { Nakamura, R., } \\
\text { Ishida, K., Tomita, } \\
\text { Y(1999)[16] } \\
\end{array}$ & $\begin{array}{l}\text { Bulletin of the School of } \\
\text { Allied Medical Sciences, } \\
\text { Nagasaki University 13, } \\
\text { 103-107. }\end{array}$ & $\begin{array}{l}\text { The caretakers of persons, using day care service in a } \\
\text { clinic, about the Long Term Care Insurance. }\end{array}$ & Questionnaire. & $\begin{array}{l}\text { Questionnaire } \\
\text { research }\end{array}$ & Staff & Governance \\
\hline $\begin{array}{l}\text { Hirayama, S., } \\
\text { Kanemitsu, Y., } \\
\text { Shindo, } \\
T(1999)[17]\end{array}$ & $\begin{array}{l}\text { Kawasaki journal of } \\
\text { medical welfare } 9(1), 55- \\
60 .\end{array}$ & $\begin{array}{l}92 \text { home caregivers who had suffered bereavement } \\
\text { within the past one half to } 3 \text { years. }\end{array}$ & $\begin{array}{l}\text { The quality and quantity of their perceived social } \\
\text { support was analyzed from the viewpoints of the kinds } \\
\text { and length of time of that support. }\end{array}$ & $\begin{array}{l}\text { Questionnaire } \\
\text { research }\end{array}$ & Staff & Others \\
\hline $\begin{array}{l}\text { Yokoyama, } M \\
\text { (1999)[8] }\end{array}$ & $\begin{array}{l}\text { Kawasaki journal of } \\
\text { medical welfare } 9(2), \\
\text { 191-200. }\end{array}$ & $\begin{array}{l}114 \text { persons who participated in the 1st class of home } \\
\text { helper training school. }\end{array}$ & The set questionnaire in question paper. & $\begin{array}{l}\text { Questionnaire } \\
\text { research }\end{array}$ & Staff & Home care \\
\hline
\end{tabular}


Table 3: continued

\begin{tabular}{|c|c|c|c|c|c|c|}
\hline $\begin{array}{l}\text { Hashimoto, } H \\
\text { (2000)[18] }\end{array}$ & $\begin{array}{l}\text { Kawasaki journal of } \\
\text { medical welfare } 10(1), \\
25-32 .\end{array}$ & $\begin{array}{l}\text { The ethical codes of conduct of professionals working } \\
\text { at medical welfare institutions. }\end{array}$ & $\begin{array}{l}\text { The ethical codes of conduct of professionals working } \\
\text { at medical welfare institutions were divided into } \\
\text { following three categories: 1) The relationship } \\
\text { between the professionals and their patients: 2) the } \\
\text { relationship among professionals and other kinds of } \\
\text { professionals (including institutions), and: } 3 \text { ) whether } \\
\text { the professionals can intervene in the relationship } \\
\text { between other professionals and their patients to } \\
\text { advocate for them. }\end{array}$ & $\begin{array}{l}\text { Related } \\
\text { document } \\
\text { research }\end{array}$ & Staff & Governance \\
\hline $\begin{array}{l}\text { Uchida, F } \\
(2000)[19]\end{array}$ & $\begin{array}{l}\text { Kawasaki journal of } \\
\text { medical welfare } 10(2) \text {, } \\
219-224 \text {. }\end{array}$ & $\begin{array}{l}\text { A persistent disturbance of consciousness patient } \\
\text { Okayama prefecture. }\end{array}$ & Question by a mailing method. & $\begin{array}{l}\text { Questionnaire } \\
\text { research }\end{array}$ & Both & $\begin{array}{l}\text { Caregiver } \\
\text { awareness }\end{array}$ \\
\hline $\begin{array}{l}\text { Hitomi, H., } \\
\text { Nakamura, Y., } \\
\text { Osawa, G., } \\
\text { Miyahara, S., } \\
\text { Tokuyama, C., } \\
\text { Ogawa, T } \\
(2000)[20]\end{array}$ & $\begin{array}{l}\text { Kawasaki journal of } \\
\text { medical welfare } 10(1) \text {, } \\
87-95 \text {. }\end{array}$ & $\begin{array}{l}\text { Two rural areas were selected at random from each } \\
\text { prefecture in Japan. }\end{array}$ & $\begin{array}{l}\text { The questionnaire requested information about: 1) } \\
\text { The number of elderly people, 2) The number of } \\
\text { elderly people who died and the number who died at } \\
\text { home, and 3) The type of social services available. } \\
\text { More detailed information was also requested about } \\
\text { those who die at home, including 1) The cause of } \\
\text { death, 2) Age at death, 3) Condition of the patient at } \\
\text { the time of death, 4) The type of social services being } \\
\text { used for the patient, and 5) Whether the patient or } \\
\text { family members had requested that the patient would } \\
\text { be allowed to die at home or not. }\end{array}$ & $\begin{array}{l}\text { Questionnaire } \\
\text { research }\end{array}$ & Both & Home care \\
\hline $\begin{array}{l}\text { Mihara, } H ., \\
\text { Yokoyama, M., } \\
\text { Minemoto, K } \\
(2000)[21]\end{array}$ & $\begin{array}{l}\text { Bulletin of the School of } \\
\text { Nursing, Yamaguchi } \\
\text { Prefectural University 4, } \\
20-25 .\end{array}$ & $\begin{array}{l}\text { One hundred-fifty careworkers in four nursing and } \\
\text { residential homes were selected as research samples. }\end{array}$ & $\begin{array}{l}\text { Focusing on perceptions about carework by } \\
\text { careworkers held in nursing and residential home for } \\
\text { the aged. }\end{array}$ & $\begin{array}{l}\text { Questionnaire } \\
\text { research }\end{array}$ & Staff & $\begin{array}{l}\text { Caregiver } \\
\text { awareness }\end{array}$ \\
\hline $\begin{array}{l}\text { Nakamura, Y., } \\
\text { Miyahara, S., } \\
\text { Hitomi, H., Ogawa, } \\
T(2000)[22] \\
\end{array}$ & $\begin{array}{l}\text { Kawasaki journal of } \\
\text { medical welfare } 10(2) \text {, } \\
225-230 \text {. }\end{array}$ & 18 visiting nursing stations in Osaka City. & Questionnaires by mailing method. & $\begin{array}{l}\text { Questionnaire } \\
\text { research }\end{array}$ & Both & Home care \\
\hline $\begin{array}{l}\text { Hiroe, H., Osawa, } \\
\text { G., Nakamura, Y., } \\
\text { Ogawa, T., } \\
\text { Nakanishi, K., } \\
\text { Ehara, A } \\
(2000)[23]\end{array}$ & $\begin{array}{l}\text { Kawasaki journal of } \\
\text { medical welfare } 10(2) \text {, } \\
273-284 \text {. }\end{array}$ & 417 care workers who attended on elderly people & $\begin{array}{l}\text { The grief process two years after the death of an aged } \\
\text { family member was examined by questionnaire. }\end{array}$ & $\begin{array}{l}\text { Questionnaire } \\
\text { research }\end{array}$ & Staff & $\begin{array}{l}\text { Elderly } \\
\text { lifestyle }\end{array}$ \\
\hline $\begin{array}{l}\text { Nagae, } H ., \text { Naruse, } \\
\text { K., Kawagoe, } H \\
(2000)[24]\end{array}$ & $\begin{array}{l}\text { Bulletin of St. Luke's } \\
\text { College of Nursing } 26 \text {, } \\
31-43 \text {. }\end{array}$ & $\begin{array}{l}\text { Nursing records of seven cases and seven nurses } \\
\text { who cared them were interviewed for defining } \\
\text { contents of nursing supports. }\end{array}$ & $\begin{array}{l}\text { Interviewing for defining contents of nursing } \\
\text { supports. }\end{array}$ & $\begin{array}{l}\text { Nursing } \\
\text { report }\end{array}$ & Staff & Home care \\
\hline $\begin{array}{l}\text { Higuchi, } K \\
\text { (2000)[25] }\end{array}$ & $\begin{array}{l}\text { Memoirs of Ashikaga } \\
\text { Junior College 20(1), } \\
\text { 73-81. }\end{array}$ & 14 home-nursing-care users of a nursing station. & $\begin{array}{l}\text { It interviews after the end of assistance, helping a } \\
\text { person requiring care. }\end{array}$ & $\begin{array}{l}\text { Interview } \\
\text { research }\end{array}$ & Staff & Home care \\
\hline
\end{tabular}


Table 3: continued

\begin{tabular}{|c|c|c|c|c|c|c|}
\hline $\begin{array}{l}\text { Bessho, Y., Hosoya, } \\
\text { T., Hasegawa, M., } \\
\text { Yshida, Y., Kitade, } \\
\text { J., Agata, R., } \\
\text { Kawabata, A } \\
(2000)[26]\end{array}$ & $\begin{array}{l}\text { Journal of Fukui } \\
\text { Medical University 1(3), } \\
\text { 495-509. }\end{array}$ & $\begin{array}{l}\text { Three staffs in three home nursing station Fukui, F } \\
\text { city, and three experienced in rehabilitation }\end{array}$ & $\begin{array}{l}\text { Reporting collaborated ways of three cases' } \\
\text { rehabilitation care practiced by Ns and PTs. The Ns } \\
\text { assessed physical and mental health, activities of } \\
\text { daily living, and the PTs assessed physical function } \\
\text { and mobility level. After setting the goal of the } \\
\text { program, they exchanged information along the } \\
\text { process of care and recorded them. The Ns and the } \\
\text { PTs evaluated the clients' goal achievements. }\end{array}$ & $\begin{array}{l}\text { Nursing } \\
\text { report }\end{array}$ & Staff & Home care \\
\hline $\begin{array}{l}\text { Bessho, Y., Hosoya, } \\
\text { T., Kitade, J., } \\
\text { Agata, R., } \\
\text { Kawabata, A } \\
(2000)[27]\end{array}$ & $\begin{array}{l}\text { Journal of Fukui } \\
\text { Medical University 1(1), } \\
\text { 191-198. }\end{array}$ & $\begin{array}{l}63 \text { persons at the home elderly requiring nursing care } \\
\text { of the Fukui } F \text { city, with no dementia at bedridden } \\
\text { degree rank } B-C \text {, and they are the level I. }\end{array}$ & $\begin{array}{l}\text { The survey was conducted on rehabilitation programs } \\
\text { of sixty-two bed-ridden elderly clients who agreed to } \\
\text { join this study by asking their home care nurses to } \\
\text { complete questionnaire. }\end{array}$ & $\begin{array}{l}\text { Interview } \\
\text { research }\end{array}$ & Staff & Home care \\
\hline $\begin{array}{l}\text { Saeki, K., Miura, } \\
\text { M., Kido, T., } \\
\text { Tsukasaki K., } \\
\text { Kimura, } R \\
(2001)[28]\end{array}$ & $\begin{array}{l}\text { Memoirs of School of } \\
\text { Health Sciences Faculty } \\
\text { of Medicine Kanazawa } \\
\text { University 24(2), 39-46. }\end{array}$ & 187 married female teachers. & $\begin{array}{l}\text { With a support of Women's Division in the Teacher's } \\
\text { Union of S city, blank questionnaires were distributed } \\
\text { to watch kindergarten, elementary and junior high } \\
\text { school in S city. }\end{array}$ & $\begin{array}{l}\text { Questionnaire } \\
\text { research }\end{array}$ & Staff & $\begin{array}{l}\text { Caregiver } \\
\text { awareness }\end{array}$ \\
\hline $\begin{array}{l}\text { Matsui, T., Okada, } \\
\text { S (2001)[29] }\end{array}$ & $\begin{array}{l}\text { Bulletin of Osaka } \\
\text { Prefectural College of } \\
\text { Health Sciences, 55-62. }\end{array}$ & $\begin{array}{l}2,211 \text { of care and a welfare staff in a home care } \\
\text { support center. }\end{array}$ & A cross-sectional mailed survey. & $\begin{array}{l}\text { Questionnaire } \\
\text { research }\end{array}$ & Staff & $\begin{array}{l}\text { Caregiver } \\
\text { awareness }\end{array}$ \\
\hline Lee, $Y(2001)[30]$ & $\begin{array}{l}\text { Kawasaki journal of } \\
\text { medical welfare 11(2), } \\
255-260 \text {. }\end{array}$ & "Care Conference" for one community, "A-cho". & $\begin{array}{l}\text { Interviewing the public official assigned to the Care } \\
\text { Conference on Social Welfare together with the } \\
\text { social worker who is its chairperson and four men } \\
\text { who are staffs members. }\end{array}$ & $\begin{array}{l}\text { Interview } \\
\text { research }\end{array}$ & Staff & $\begin{array}{l}\text { Community } \\
\text { welfare }\end{array}$ \\
\hline $\begin{array}{l}\text { Tsukahara, T., } \\
\text { Miyahara, } S \\
\text { (2001)[31] }\end{array}$ & $\begin{array}{l}\text { Kawasaki journal of } \\
\text { medical welfare 11(1), } \\
17-24 \text {. }\end{array}$ & $\begin{array}{l}\text { The heads of nurses of } 530 \text { facilities selected by } \\
\text { systematic sampling from } 2,770 \text { special nursing } \\
\text { homes for the elderly established before } 1993 \text {. }\end{array}$ & $\begin{array}{l}\text { A survey of the present status of terminal care at } \\
\text { special nursing homes for the elderly sending a } \\
\text { questionnaire. }\end{array}$ & $\begin{array}{l}\text { Questionnaire } \\
\text { research }\end{array}$ & Staff & $\begin{array}{l}\text { Field survey } \\
\text { in facility }\end{array}$ \\
\hline $\begin{array}{l}\text { Kunitake, } K ., \\
\text { Furukawa, H., } \\
\text { Noguchi, F } \\
(2001)[32]\end{array}$ & $\begin{array}{l}\text { Journal of the faculty of } \\
\text { nursing and nutrition } \\
\text { Siebold university of } \\
\text { Nagasaki 1, 7-19. }\end{array}$ & 12 elderly people and 12 caregivers. & $\begin{array}{l}\text { They belonged to the two groups, B and C, by using } \\
\text { of the Activities of Daily Living }(A D L) \text { Scale made by } \\
\text { the Ministry of Health \& Welfare. The researcher } \\
\text { face to face interviewed them and the caregiver. }\end{array}$ & $\begin{array}{l}\text { Interview } \\
\text { research }\end{array}$ & Staff & $\begin{array}{l}\text { Caregiver } \\
\text { awareness }\end{array}$ \\
\hline $\begin{array}{l}\text { Tsukada, M., Uno., } \\
\text { Kamiyama, M., } \\
\text { Kobayashi, H., } \\
\text { Tamura, Y., } \\
\text { Matsuda, E } \\
(2001)[33]\end{array}$ & $\begin{array}{l}\text { Higher brain function } \\
\text { research } 21 \text { (4), 236- } \\
241 .\end{array}$ & $\begin{array}{l}\text { A total of } 364 \text { subjects with cerebral vascular injury } \\
\text { receiving community-based speech therapy in Tokyo } \\
\text { participated in the survey. }\end{array}$ & $\begin{array}{l}\text { A survey was conducted to study the situation of } \\
\text { adults who are in speech therapy at community-based } \\
\text { health-care and social-welfare facilities }\end{array}$ & $\begin{array}{l}\text { Questionnaire } \\
\text { research }\end{array}$ & User & $\begin{array}{l}\text { Field survey } \\
\text { in facility }\end{array}$ \\
\hline $\begin{array}{l}\text { Miyahara, } S \\
(2001)[34]\end{array}$ & $\begin{array}{l}\text { Kawasaki journal of } \\
\text { medical welfare 11(1), 9- } \\
15 .\end{array}$ & $\begin{array}{l}\text { All Residents at home A in Okayama prefecture } \\
\text { (capacity: 110person) between } 1993 \text { and } 1998 .\end{array}$ & $\begin{array}{l}\text { The actual conditions were studied by perusing } \\
\text { medical records and referring to the deaths } \\
\text { certificates, ect. }\end{array}$ & $\begin{array}{l}\text { Related } \\
\text { document } \\
\text { research } \\
\end{array}$ & Staff & Staffing \\
\hline $\begin{array}{l}\text { Segawa, } M \\
(2001)[35]\end{array}$ & $\begin{array}{l}\text { Kawasaki journal of } \\
\text { medical welfare } 11(2) \text {, } \\
277-286 \text {. }\end{array}$ & $\begin{array}{l}\text { Three non-functional case of the sub-system of patient } \\
\text { and main care-giver. }\end{array}$ & $\begin{array}{l}\text { Studying families that are taking care of old people, } \\
\text { looking at the family structurally according to the } \\
\text { system-theory approach. }\end{array}$ & $\begin{array}{l}\text { Observational } \\
\text { research }\end{array}$ & Both & Home care \\
\hline
\end{tabular}


Table 3: continued

\begin{tabular}{|c|c|c|c|c|c|c|}
\hline $\begin{array}{l}\text { Sawada, } Y \\
(2002)[36]\end{array}$ & $\begin{array}{l}\text { Kwansei Gakuin policy } \\
\text { studies review 1, 1-17. }\end{array}$ & $\begin{array}{l}\text { A data of } 715 \text { nursing home care workers drawn from } \\
42 \text { nursing homes located western part of Japan. }\end{array}$ & Four hypotheses were tested by F-test. & $\begin{array}{l}\text { Questionnaire } \\
\text { research }\end{array}$ & Staff & $\begin{array}{l}\text { Caregiver } \\
\text { awareness }\end{array}$ \\
\hline $\begin{array}{l}\text { Kono, } M ., \\
\text { Kuroda, } K \\
(2002)[37]\end{array}$ & $\begin{array}{l}\text { Bulletin of Aino Gakuin } \\
15,79-87 .\end{array}$ & $\begin{array}{l}378 \text { of special elderly nursing home in the Keihanshin } \\
\text { area. }\end{array}$ & The questionnaire by a mailing method & $\begin{array}{l}\text { Questionnaire } \\
\text { research }\end{array}$ & Staff & $\begin{array}{l}\text { Field survey } \\
\text { in facility }\end{array}$ \\
\hline $\begin{array}{l}\text { Washio, M., Arai, Y., } \\
\text { Izumi, H., } \\
\text { Mori, } M(2002)[38]\end{array}$ & $\begin{array}{l}\text { Japanese journal of } \\
\text { geriatrics } 40,147-155 .\end{array}$ & $\begin{array}{l}\text { Caregivers who took care of frail elderly persons } 1 \\
\text { year after the introduction of the public long-term } \\
\text { care insurance system (i.e., kaigo hoken) in the } \\
\text { northern part of Fukuoka Prefecture, Kyushu, Japan. }\end{array}$ & $\begin{array}{l}\text { Forty-seven caregivers answered a self-administered } \\
\text { questionnaire involving the Japanese version of the } \\
\text { Zarit Caregiver Burden Interview (ZBI) and thus } \\
\text { described their own caregiving situation. }\end{array}$ & $\begin{array}{l}\text { Questionnaire } \\
\text { research }\end{array}$ & Staff & $\begin{array}{l}\text { Caregiver } \\
\text { awareness }\end{array}$ \\
\hline $\begin{array}{l}\text { Mahune, T., Ando, } \\
\text { S., } \\
\text { Sema, A (2002)[39] }\end{array}$ & $\begin{array}{l}\text { Niigata Medical } \\
\text { Journal 116(2), 78-89. }\end{array}$ & $\begin{array}{l}\text { Many materials related to the Community Care } \\
\text { System for Olds, and interview to } 8 \text { Main Care Giver } \\
\left(M{ }^{*}{ }^{*} G\right) \text { co-residence with Alzheimer' desease. }\end{array}$ & $\begin{array}{l}\text { The questionnaire of the interview are held MMS, } \\
\text { FAST, etc for Alzheimer's Desease and QOL of } \\
\text { Health \& Life, etc for } M{ }^{*}{ }^{*} \text { G. RESULTS. }\end{array}$ & $\begin{array}{l}\text { Related } \\
\text { document } \\
\text { research }\end{array}$ & Both & $\begin{array}{l}\text { State of } \\
\text { dementia }\end{array}$ \\
\hline Shindo, $S(2002)[40]$ & $\begin{array}{l}\text { Bulletin of College of } \\
\text { Allied Medical Science } \\
\text { Akita University 10(2), } \\
\text { 165-170. }\end{array}$ & $\begin{array}{l}50 \text { residents. ( } 12 \text { men, } 38 \text { women aged } 53 \text { to } 94 \text { years, } \\
\text { mean age } 75.5 y e a r s)\end{array}$ & $\begin{array}{l}\text { Analyzing their ADL (mobility, eating, toileting, } \\
\text { bathing, grooming, dressing and communication) for } \\
\text { five years after institutionalization. }\end{array}$ & $\begin{array}{l}\text { Observational } \\
\text { research }\end{array}$ & User & $\begin{array}{l}\text { Changing } \\
\text { nursing } \\
\text { care level }\end{array}$ \\
\hline $\begin{array}{l}\text { Minematsu, } A \\
\text { (2003)[41] }\end{array}$ & $\begin{array}{l}\text { Japanese journal of } \\
\text { occupational medicine } \\
\text { and traumatology } 51 \text {, } \\
405-409 .\end{array}$ & $\begin{array}{l}19 \text { of care givers who works in a certain welfare } \\
\text { institution for elderly people, } 38 \text { students who aim at } \\
\text { a care worker in a certain welfare vocational school. }\end{array}$ & $\begin{array}{l}\text { The questionnaire concerning rehabilitation } \\
\text { knowledge and technology about the occupational } \\
\text { consciousness of a care job person and a student. }\end{array}$ & $\begin{array}{l}\text { Questionnaire } \\
\text { research }\end{array}$ & Staff & $\begin{array}{l}\text { Human } \\
\text { resource } \\
\text { development }\end{array}$ \\
\hline $\begin{array}{l}\text { Morimoto, } H \\
(2003)[42]\end{array}$ & $\begin{array}{l}\text { Kawasaki journal of } \\
\text { medical welfare 13(2), } \\
262-269 \text {. }\end{array}$ & $\begin{array}{l}157 \text { care staffs in study } 1 \text { and } 201 \text { care staff in study } 2 \\
\text { were examined respectively. }\end{array}$ & ANOVA and path analysis. & $\begin{array}{l}\text { Questionnaire } \\
\text { research }\end{array}$ & Staff & $\begin{array}{l}\text { Caregiver } \\
\text { awareness }\end{array}$ \\
\hline $\begin{array}{l}\text { Kobayashi, A., } \\
\text { Yajima, } M ., \\
\text { Umebayashi, K., } \\
\text { Kobayashi, K., } \\
\text { Ohno, } A(2003)[43]\end{array}$ & $\begin{array}{l}\text { Gumma Paz Gakuen } \\
\text { College 5(1), 33-46. }\end{array}$ & $\begin{array}{l}\text { In-home services users living in a town in Gunma } \\
\text { Prefecture. After mailing the questionnaires to the } \\
\text { subjects, we visited their houses and collected the } \\
\text { questionnaires. }\end{array}$ & $\begin{array}{l}\text { Questionnaires were used to assess the quality of in- } \\
\text { home services by taking a hard look at the long term } \\
\text { insurance system. }\end{array}$ & $\begin{array}{l}\text { Questionnaire } \\
\text { research }\end{array}$ & User & $\begin{array}{l}\text { Care } \\
\text { assessment }\end{array}$ \\
\hline $\begin{array}{l}\text { Higuchi, K., } \\
\text { Dai, Y., } \\
\text { Wakasa, } R \\
(2003)[44] \\
\end{array}$ & $\begin{array}{l}\text { The Journal of } \\
\text { Juntendo Medical } \\
\text { College of Nursing 14, } \\
\text { 85-94. }\end{array}$ & $\begin{array}{l}56 \text { after the end of the first half of junior home- } \\
\text { health-care in nursing system junior college real. }\end{array}$ & $\begin{array}{l}\text { The contents described by the record thing of the } \\
\text { "conclusion of home-health-care training" of a } \\
\text { student are deciphered in detail. }\end{array}$ & $\begin{array}{l}\text { Nursing } \\
\text { report }\end{array}$ & Staff & $\begin{array}{l}\text { Human } \\
\text { resource } \\
\text { developmen } \\
t\end{array}$ \\
\hline $\begin{array}{l}\text { Yamamoto, T., Aoki, } \\
\text { Y., Kawabe, F., } \\
\text { Takahashi, S., } \\
\text { Nagata, A., Wazumi, } \\
\text { Y(2003)[45] }\end{array}$ & $\begin{array}{l}\text { Journal of School of } \\
\text { Nursing, Chiba } \\
\text { University 25, 45-51. }\end{array}$ & $\begin{array}{l}\text { A nurse who applied nursing practice methodology } \\
\text { into paper patients. }\end{array}$ & $\begin{array}{l}\text { Intending to make what kind of knowledge was used } \\
\text { in judgment of a nurse who applied nursing practice } \\
\text { methodology into paper patients. }\end{array}$ & Others & Staff & $\begin{array}{l}\text { Human } \\
\text { resource } \\
\text { developmen } \\
t\end{array}$ \\
\hline $\begin{array}{l}\text { Hisano, S., Shimizu, } \\
H(2003)[46]\end{array}$ & $\begin{array}{l}\text { Journal of health } \\
\text { sciences Hiroshima } \\
\text { University 3(1), 21-36. }\end{array}$ & $\begin{array}{l}157 \text { care staff in study } 1 \text { and } 201 \text { care staff in study } 2 \\
\text { were examined respectively. }\end{array}$ & ANOVA and path analysis. & $\begin{array}{l}\text { Literature } \\
\text { research }\end{array}$ & Staff & $\begin{array}{l}\text { Field survey } \\
\text { in facility }\end{array}$ \\
\hline Koike, $S$ (2004)[47] & $\begin{array}{l}\text { Journal of the Keio } \\
\text { Medical Society 81(4), } \\
271-286 .\end{array}$ & All municipalities in Japan. & $\begin{array}{l}\text { Questionnaires were sent to all municipalities in } \\
\text { Japan in November } 1999 \text { (before the introduction of } \\
\text { (LTCI) and in 2001(after the introduction of LTCI). }\end{array}$ & $\begin{array}{l}\text { Questionnaire } \\
\text { research }\end{array}$ & Staff & $\begin{array}{l}\text { Community } \\
\text { welfare }\end{array}$ \\
\hline
\end{tabular}


Table 3: continued

\begin{tabular}{|c|c|c|c|c|c|c|}
\hline $\begin{array}{l}\text { Nitta, S., Mochizuki, } \\
\text { N., Shimizu, Y., } \\
\text { Uemura, } N \\
(2005)[48]\end{array}$ & $\begin{array}{l}\text { Yamanashi Nursing } \\
\text { Journal 4(1), 27-33. }\end{array}$ & $\begin{array}{l}50 \text { elderly receiving both day-services and home- } \\
\text { health nursing. }\end{array}$ & $\begin{array}{l}\text { A statistical work about the copy data of a connection } \\
\text { note. }\end{array}$ & $\begin{array}{l}\text { Related } \\
\text { document } \\
\text { research }\end{array}$ & Both & $\begin{array}{l}\text { Field survey } \\
\text { in facility }\end{array}$ \\
\hline $\begin{array}{l}\text { Mochizuki, N., Nitta, } \\
\text { S., Shimizu, Y } \\
(2005)[49]\end{array}$ & $\begin{array}{l}\text { Yamanashi Nursing } \\
\text { Journal 3(2), 27-32. }\end{array}$ & $\begin{array}{l}\text { The aged people requiring care of day-care-services } \\
\text { use eight within the prefecture, } 54 \text { nursing-care-by- } \\
\text { family-members persons living together. }\end{array}$ & $\begin{array}{l}\text { Beforehand and the posttest experimental study } \\
\text { design in an intervention group and a contrast group. }\end{array}$ & $\begin{array}{l}\text { Interview } \\
\text { research }\end{array}$ & Staff & $\begin{array}{l}\text { Caregiver } \\
\text { awareness }\end{array}$ \\
\hline $\begin{array}{l}\text { Otsu, H., Takayama, } \\
\text { S., Handa, Y., } \\
\text { Ogawa, C., Nomura, } \\
\text { S. }(2006)[50]\end{array}$ & $\begin{array}{l}\text { Humanity and science: } \\
\text { journal of the Faculty } \\
\text { of Health and Welfare } \\
6(1), 25-35 .\end{array}$ & $\begin{array}{l}\text { Participants ten elderly residents with Alzheimer's } \\
\text { disease living in nursing homes whose age was over } \\
\text { sixty-five and who could communicate with others } \\
\text { verbally and express their opinions. }\end{array}$ & $\begin{array}{l}\text { With the ultimate aim of exploring methods of nursing } \\
\text { care appropriate to their feelings while wandering. }\end{array}$ & $\begin{array}{l}\text { Observational } \\
\text { research }\end{array}$ & User & $\begin{array}{l}\text { State of } \\
\text { dementia }\end{array}$ \\
\hline $\begin{array}{l}\text { Saito, Y., Matsumoto, } \\
\text { M., Ohta, S., } \\
\text { Yoshinaga, T } \\
(2006)[51]\end{array}$ & $\begin{array}{l}\text { Kawasaki journal of } \\
\text { medical welfare 15(2), } \\
\text { 529-537. }\end{array}$ & $\begin{array}{l}\text { The } 9 \text { subjects were classified into an independent } \\
\text { group, a partial assisted group and an assisted group } \\
\text { according to mobility. }\end{array}$ & $\begin{array}{l}\text { The living location and activity in the daytime, sleep- } \\
\text { wake rhythms, sitting pressures and sitting postures } \\
\text { before and after adoption of technical aids were } \\
\text { investigated. }\end{array}$ & Experiment & User & $\begin{array}{l}\text { Care } \\
\text { support, }\end{array}$ \\
\hline $\begin{array}{l}\text { Furuse, M., Saeki, } K \\
\text { (2006)[52] }\end{array}$ & $\begin{array}{l}\text { Journal of the Tsuruma } \\
\text { Health Science Society } \\
\text { Kanazawa University } \\
29(2), 55-64 .\end{array}$ & $\begin{array}{l}\text { The study was performed on } 14 \text { Japanese visiting } \\
\text { nurses data collection. }\end{array}$ & $\begin{array}{l}\text { The study was performed on } 14 \text { Japanese visiting } \\
\text { nurses using semi-structured interviews and the M- } \\
\text { GTA. }\end{array}$ & $\begin{array}{l}\text { Interview } \\
\text { research }\end{array}$ & Staff & $\begin{array}{l}\text { Care } \\
\text { support, }\end{array}$ \\
\hline $\begin{array}{l}\text { Shinagawa, } Y ., \\
\text { Kishimoto, T., Ohta, } \\
\text { S (2006)[53] }\end{array}$ & $\begin{array}{l}\text { Kawasaki journal of } \\
\text { medical welfare } 16(1) \\
121-128 .\end{array}$ & Monitored data at home for 25 months. & $\begin{array}{l}\text { To establish detection method of health condition of } \\
\text { elderly people living alone, we statistically analyzed } \\
\text { monitored data at home for } 25 \text { months. }\end{array}$ & Experiment & User & Others \\
\hline $\begin{array}{l}\text { Nishikawa, } T \\
\text { (2006)[54] }\end{array}$ & $\begin{array}{l}\text { Journal of the Socio- } \\
\text { Cultural Research } \\
\text { Institute, Ryukoku } \\
\text { University } 8,189-205 . \\
\end{array}$ & Type A Moderate Fee Senior Citizen Home. & $\begin{array}{l}\text { Investigating the situation of Type A Moderate Fee } \\
\text { Senior Citizen Home in November } 2004 .\end{array}$ & $\begin{array}{l}\text { Questionnaire } \\
\text { research }\end{array}$ & Staff & $\begin{array}{l}\text { Field survey } \\
\text { in facility }\end{array}$ \\
\hline $\begin{array}{l}\text { Matsumoto, } K ., \\
\text { Wakasaki, } A \\
(2006)[55]\end{array}$ & $\begin{array}{l}\text { Kawasaki journal of } \\
\text { medical 6(1), 67-72. }\end{array}$ & $\begin{array}{l}36 \text { senior citizens of } 65 \text { years or more based on the } \\
\text { report of authors' preceding this time. }\end{array}$ & $\begin{array}{l}\text { The qualitative factor search type of the current state } \\
\text { of Successful Aging was researched using a } \\
\text { questionnaire survey. }\end{array}$ & $\begin{array}{l}\text { Questionnaire } \\
\text { research }\end{array}$ & User & $\begin{array}{l}\text { Elderly } \\
\text { lifestyle }\end{array}$ \\
\hline $\begin{array}{l}\text { Futoyu, Y., Okada, } \\
\text { Y., Shinpou, T., } \\
\text { Okuyama, M., } \\
\text { Takeda, K., } \\
\text { Kawaguti, T } \\
(2006)[56]\end{array}$ & $\begin{array}{l}\text { Kawasaki journal of } \\
\text { medical 15(2), 423-431. }\end{array}$ & $\begin{array}{l}89 \text { persons of the solitude aged } 65 \text { and over which } \\
\text { resides in the Tomiyama area, and an elderly-people } \\
\text { husband-and-wife household. }\end{array}$ & Hearing investigation & $\begin{array}{l}\text { Interview } \\
\text { research }\end{array}$ & User & $\begin{array}{l}\text { Community } \\
\text { welfare }\end{array}$ \\
\hline $\begin{array}{l}\text { Takeda, K., Futoyu, } \\
Y(2006)[57]\end{array}$ & $\begin{array}{l}\text { Kawasaki journal of } \\
\text { medical 16(1), 53-66. }\end{array}$ & $\begin{array}{l}\text { Nine previous papers containing concrete } \\
\text { information about the spirituality of elderly Japanese. }\end{array}$ & $\begin{array}{l}\text { Analyzing with reference to literature, to extract } \\
\text { concepts related to spirituality and put them into } \\
\text { some structural relationship }\end{array}$ & $\begin{array}{l}\text { Literature } \\
\text { research }\end{array}$ & User & $\begin{array}{l}\text { Elderly } \\
\text { lifestyle }\end{array}$ \\
\hline $\begin{array}{l}\text { Moochizuki, S., } \\
\text { Yamagishi, H., } \\
\text { Iijima, S (2007)[58] }\end{array}$ & $\begin{array}{l}\text { Yamanashi Nursing } \\
\text { Journal 5(2), 19-24. }\end{array}$ & $\begin{array}{l}\text { Using random sampling, unsigned questionnaires } \\
\text { were mailed to public health nurses at } 40 \\
\text { municipalities throughout Japan. }\end{array}$ & Unsigned questionnaires. & $\begin{array}{l}\text { Questionnaire } \\
\text { research }\end{array}$ & Staff & $\begin{array}{l}\text { human } \\
\text { resource } \\
\text { development }\end{array}$ \\
\hline $\begin{array}{l}\text { Suhiura, } K ., \\
\text { Ito, } \text { M., } \\
\text { Mikami, } H \\
(2007)[59]\end{array}$ & $\begin{array}{l}\text { Japanese journal of } \\
\text { geriatrics } 44(6), 717 \text { - } \\
725 .\end{array}$ & $\begin{array}{l}\text { 1,818 users of the public Long-term Care Insurance } \\
\text { Act, randomly stratified and sampled in Higashi- } \\
\text { osaka city, Osaka prefecture. Data }\end{array}$ & $\begin{array}{l}\text { Data were collected through mailed, anonymous self- } \\
\text { report questionnaires. }\end{array}$ & $\begin{array}{l}\text { Questionnaire } \\
\text { research }\end{array}$ & Staff & $\begin{array}{l}\text { Caregiver } \\
\text { awareness }\end{array}$ \\
\hline
\end{tabular}


Table 3: continued

\begin{tabular}{|c|c|c|c|c|c|c|}
\hline Ichiki, $N(2007)[60]$ & $\begin{array}{l}\text { Bulletin of Kyushu } \\
\text { women's university } \\
43(3), 1-20 .\end{array}$ & The nursing insurance system. & $\begin{array}{l}\text { Providing the universal care service of sincerity in } \\
\text { this paper in the nursing insurance system. }\end{array}$ & others & staff & $\begin{array}{l}\text { community } \\
\text { welfare }\end{array}$ \\
\hline $\begin{array}{l}\text { Ozawa, M., Mizuno, } \\
\text { M., Sato, E., Takaya, } \\
\text { T., Masaki, H., } \\
\text { Hirose, C., Takeo, K } \\
\text { (2007)[61] }\end{array}$ & $\begin{array}{l}\text { J Nurs Studies N C N J } \\
6(1), 3-9 .\end{array}$ & $\begin{array}{l}\text { Type of hospital hired new nurses, and trained them } \\
\text { for } 11 \text { nursing skills considered to be particularly } \\
\text { related to patient safety. }\end{array}$ & $\begin{array}{l}\text { An original questionnaire is developed and } \\
\text { investigated. }\end{array}$ & $\begin{array}{l}\text { Questionnaire } \\
\text { research }\end{array}$ & Staff & $\begin{array}{l}\text { Human } \\
\text { resource } \\
\text { development }\end{array}$ \\
\hline $\begin{array}{l}\text { Igarashi, } H \\
(2008)[62]\end{array}$ & $\begin{array}{l}\text { Yamanashi Nursing } \\
\text { Journal 6(2), 25-30. }\end{array}$ & 153 nursing persons of a home nursing station user. & $\begin{array}{l}\text { The account type question paper investigation of self- } \\
\text { was used for investigation. In distribution of a survey } \\
\text { form, it is cooperation of } 8 \text { home nursing stations of } \\
\text { A prefecture. }\end{array}$ & $\begin{array}{l}\text { Questionnaire } \\
\text { research }\end{array}$ & Staff & Home care \\
\hline $\begin{array}{l}\text { Nakanishi, J., } \\
\text { Morishita, } M \\
\text { (2008)[63] }\end{array}$ & $\begin{array}{l}\text { Bulletin of Nagasaki } \\
\text { University School of } \\
\text { Health Sciences. } 20(2), \\
9-18 .\end{array}$ & 759 A school-of-nursing graduates. & $\begin{array}{l}\text { Postal survey was conducted with unsigned } \\
\text { questionnaires. }\end{array}$ & $\begin{array}{l}\text { Questionnaire } \\
\text { research }\end{array}$ & Staff & $\begin{array}{l}\text { Community } \\
\text { welfare }\end{array}$ \\
\hline $\begin{array}{l}\text { Mochizuki, S., Mogi, } \\
\text { M,. Iijima, S. } \\
\text { (2009)[64] }\end{array}$ & $\begin{array}{l}\text { Yamanashi Nursing } \\
\text { Journal 8(1), 9-14. }\end{array}$ & 250 visiting nurses in A Prefecture & Unsigned questionnaires were distributed & $\begin{array}{l}\text { Questionnaire } \\
\text { research }\end{array}$ & Staff & $\begin{array}{l}\text { Caregiver } \\
\text { awareness }\end{array}$ \\
\hline $\begin{array}{l}\text { Takayama, } N ., \\
\text { Takeo, } K(2009)[65]\end{array}$ & $\begin{array}{l}\text { J Nurs Studies N C N J } \\
8(1), 1-9 .\end{array}$ & $\begin{array}{l}\text { First, an evaluation standard for measuring team } \\
\text { work and impacting factors in nursing was created } \\
\text { using existing scholarship and clinical experiences. }\end{array}$ & $\begin{array}{l}\text { Creation of the rate scale about the teamwork and the } \\
\text { factor affecting in a nursing care activity. }\end{array}$ & $\begin{array}{l}\text { Questionnaire } \\
\text { research }\end{array}$ & Staff & $\begin{array}{l}\text { Nursing } \\
\text { teamwork }\end{array}$ \\
\hline $\begin{array}{l}\text { Watanabe, } N \\
\text { (2009)[66] }\end{array}$ & $\begin{array}{l}\text { Tokiwa Journal of } \\
\text { Human Science 17, 19- } \\
28 .\end{array}$ & $\begin{array}{l}270 \text { welfare service workers, } 81 \text { care worker training } \\
\text { organization second graders. }\end{array}$ & Questionnaires. & $\begin{array}{l}\text { Questionnaire } \\
\text { research }\end{array}$ & Staff & $\begin{array}{l}\text { Caregiver } \\
\text { awareness }\end{array}$ \\
\hline $\begin{array}{l}\text { Keтиуата, } S \\
\text { (2009)[67] }\end{array}$ & $\begin{array}{l}\text { Bulletin of Graduate } \\
\text { School of Health } \\
\text { Sciences, Akita } \\
\text { University 17(2), 1-11. }\end{array}$ & 152 staff in 3 institutions in A prefecture. & $\begin{array}{l}\text { Intending to clarify the recognition of depression } \\
\text { state in dementia by care workers and nurses and } \\
\text { corresponding problems was carried out. }\end{array}$ & $\begin{array}{l}\text { Questionnaire } \\
\text { research }\end{array}$ & Staff & $\begin{array}{l}\text { State of } \\
\text { dementia }\end{array}$ \\
\hline $\begin{array}{l}\text { Fukuma, M., } \\
\text { Shiwaku, } K \\
(2010)[68]\end{array}$ & $\begin{array}{l}\text { Journal of the Japanese } \\
\text { Association of Rural } \\
\text { Medicine } 58 \text { (5), 516- } \\
525 .\end{array}$ & $\begin{array}{l}\text { The relationship between changes of care levels of } \\
\text { frail elderly people residing in Izumo City, Shimane, } \\
\text { and such factors as gender, age, activity of daily life } \\
\text { and care services utilization, in a cohort study of } \\
1965 \text { certified elderly individuals in 2000, and of } \\
2547 \text { such individuals in 2002. }\end{array}$ & $\begin{array}{l}\text { Tracking the care levels of each cohort over a two- } \\
\text { year period. }\end{array}$ & $\begin{array}{l}\text { Related } \\
\text { document } \\
\text { research }\end{array}$ & User & $\begin{array}{l}\text { Changing } \\
\text { nursing } \\
\text { care level }\end{array}$ \\
\hline $\begin{array}{l}\text { Mitoku, } K \\
\text { (2010)[69] }\end{array}$ & $\begin{array}{l}\text { Japanese Journal of } \\
\text { Tobacco Control5(1), } \\
\text { 10-17. }\end{array}$ & $\begin{array}{l}\text { 2,720 employees who were directly involved in } \\
\text { geriatric care at } 114 \text { facilities that included a special } \\
\text { care home for the aged and F geriatric health care } \\
\text { facilities under the jurisdiction of Okayama } \\
\text { Prefecture Bizen General Service Bureau and } \\
\text { Okayama Prefectural Group Home Association. }\end{array}$ & $\begin{array}{l}\text { To measure the level of stress, the "Simple Survey } \\
\text { Sheets for Occupational Stress" was used. Through } \\
57 \text { questions, stress factors were described by } 9 \\
\text { items, stress responses by } 6 \text { items and other factors } \\
\text { affecting stress responses by } 4 \text { items. }\end{array}$ & $\begin{array}{l}\text { Questionnaire } \\
\text { research }\end{array}$ & Staff & $\begin{array}{l}\text { Caregiver } \\
\text { awareness }\end{array}$ \\
\hline
\end{tabular}




\subsubsection{Classification by the research object}

First, we classified papers into three categories: a user aspect, a staff aspect, both the user aspect and the staff aspect. As a result, the papers classified as dealing with the user aspect made up 19\%, those related to the staff aspect made up 70\%, and those related to both the user aspect and the staff aspect, $11 \%$. Figure 3 depicts these.

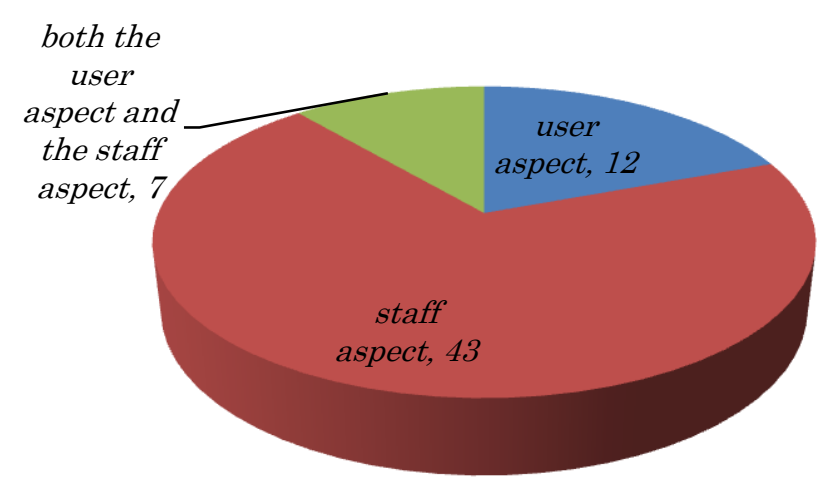

Figure 3. Classification by the research object

Yokoyama [8] showed an example of the staff aspect. He investigated home-care nurse's posture and consideration to record. As a result, it was shown that the nursing report notes which are an opportunity for staff to communicate, and the greatest need was for reports, training, and self-study of the nursing report notes.

\subsubsection{Classification by the research theme}

Second, we classified 13 categories as depicted Figure 4. As a result, the category of care giver's awareness included 16 papers; home care, 11; field survey in facility, 6; human resource development, community welfare, and governance, 5; state of dementia, elderly lifestyle, and care assessment, 3; care support, and changing nursing care level, 2; and nursing teamwork, and staffing, 1.

Totally, 57\% of the papers were classified as consisting of questionnaire research and interview research. However, none of the research results were actually approaches used.

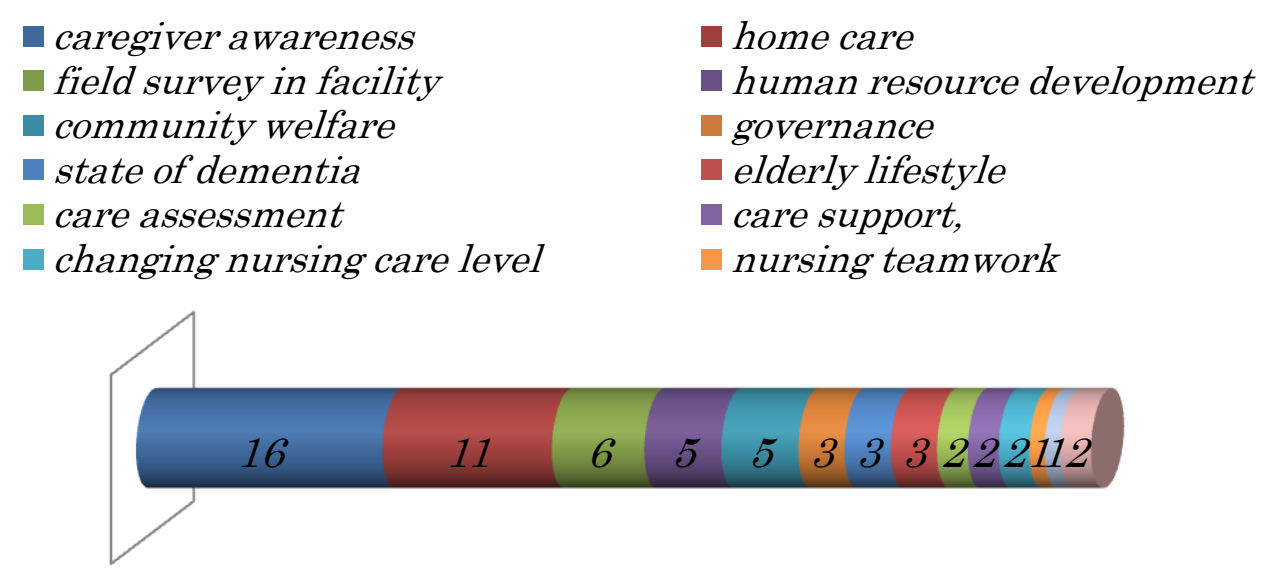

Figure 4. Classification by the research theme 
We picked up the top five researches. First, for the category of care giver's awareness, Mihara[21] focused on perceptions about care work by care workers at nursing and residential homes for the aged. The result showed that they felt that it is better for the aged to live in their own home than to stay in a nursing home. Furthermore, these care workers felt that the social status of care work is not high. Mihara proposed the necessity of movements to improve the social status of care work among care workers and social workers.

Next, for the category of home care, [35] studied families that are taking care of older people, looking at the family structurally according to the system-theory approach. As a result, it was cleared that it is possible to apply the system-theory approach to care- giving in the home.

Through a field survey in facilities, Nishikawa [54] showed the choices presented by a type A moderate fee senior citizen home. The realities are reported the urge of the selection whether A type is on the direction of "Tokutei institution" and elderly in need of nursing care is accepted positively, or place to live for an independent senior elderly as usual.

In respect to the category of human resources, Yamamoto [45] intended to make what kind of knowledge was used in judgment of a nurse who applied nursing practice methodology into paper patients. Process of thinking of the nurse who applied nursing practice methodology was described, and analyzed. As a result, the knowledge used for judgment of a nurse extended to human science, physiology, pathology and social welfare studies in depth.

In respect to the category of community welfare, Tsukada [33] showed the actual condition of those who used the speech therapist service in the community welfare system and the health facilities.

Regarding the category of governance, Hashimoto [18] proposed to clarify the advocacy functions of employees of medical welfare institutions. He divided medical welfare institutions into the following three categories: 1) The relationship between the professionals and their patients; 2) the relationship among professionals and other kinds of professionals (including those at institutions), and; 3 ) whether the professionals can intervene in the relationship between other professionals and their patients. It was found that the most important factor was to guarantee the patients' rights. A common ethical code of conduct for professionals working at medical welfare institutions needs to be proposed.

\subsubsection{Classification by the research method}

Moreover, we classified the papers by analytical method as depicted in Figure 5. As a result, the category of questionnaire research comprises 36 papers; interview research, 8; related document research, 6; nursing report; 4, observational research, 3; paper research, experiment research, 2.

Figure 5 shows that about $70 \%$ of the researches are classified as questionnaire research and interview research. However, none of the research results were used to devise an actual approach to quality improvement.

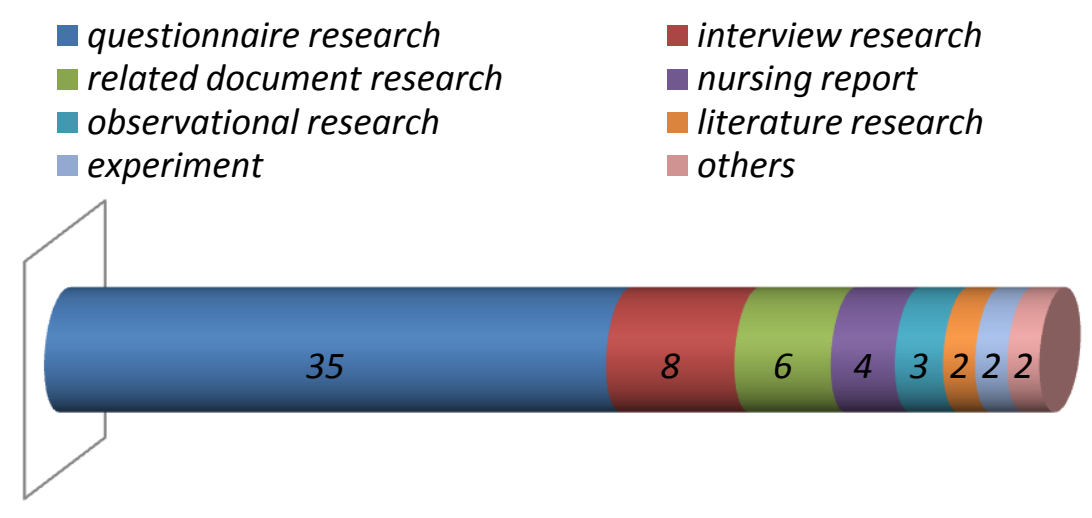

Figure 5. Classification by the research method 


\section{DISCUSSION}

In this paper, we examine the trend in research on the quality of service provided in the welfare industry. However, the trend is not directly related to the quality of service in the original paper. All researches take a partial view as themes for improving quality and have a short-term consequence.

Mochizuki [64] analyzed causal relations between occupational satisfaction and the burnout experienced by the home-care nurse. It was shown that a factor causing burnout of the home-care nurse is the lack of awareness about the profession and decreased occupational satisfaction. Additionally, it is shown that increasing awareness of the profession through job experience and in-service education may improve occupational satisfaction.

Takayama [65] analyzed team work and the related factors in the nursing care activity. As a result, it was shown that "Confidence in team work" meaning a good relationship with the superiors and colleagues has a positive influence on the "Desire for work", "Confidence in nursing", and "Job satisfaction".

It is certain that the topics of their researches included elements composing TQM. However, their researches did not aspire to TQM.

As regards the approach to improvement of patient satisfaction, there are researches that use a mental health assessment before and after. However, these researches does not seek that gone after the root cause of them and a continuing cycle of management in the following years still needs to be established. This result suggests that the concept of TQM does not percolate throughout the welfare industry unlike in manufacturing, for example, where Toyota is known for its leadership enterprise in quality management.

As regards the increasing papers about care burden or the development of human resources might indicate one direction, it is thought that it may be required to make a manual of human resource development including mental health skills for individuals.

It is quite possible that the manual of human resources development will be used for education in a general setting in the future. Ozawa [61] showed that the actual training in nursing technique focused on the novice nurse's education. It was shown that a lot of the hospitals with beds for patients in general care assigned these to the novice nurses, and most of the hospitals taught nursing technology as directly connected with patient safety. It is necessary to have efforts improving the quality of the facilities with these researches. For example, what kind of training will be effective, and reason why the training needs to do in the general care wards at the hospitals.

Furthermore, because the researches that described information storage made up about $50 \%$ of the papers, we predict increasing numbers of facilities will implement electronic health record systems or ordering systems. However, in the research on information storage, there are no original papers about a concrete system. For instance, the research by Nitta [48], investigated the actual conditions with regard to the description of the report note. We found that there was no evaluation of the electronic health record system and ordering system at the present stage in terms of their effective use. Effective use of these systems would both increase business efficiency and enable the sharing of information between staffs in the facilities and staffs among facilities.

Thus, these systems would have a positive effect on the quality of service. Hence, it seems that the importance of an engineer who is well-versed in the welfare industry arises. Moreover, people working in the welfare profession should also acquire knowledge of quality management.

Furthermore, we summarized their results at Figure 6. The chart is color-coded on Figure 1 according to the number of cases which showed the depth of red color. The deepest red is over 10, the second deepest is from 5 to 9 , the third deepest is from 1 to four, and white color is zero.

Figure 6 showed that there were many white, the results shows that there were a lot of frontier in welfare service to improve the quality of service. And we thought the important of the quality of service isn't understood very much. Particularly examples were in the dimension of "Information management system", and "Management personnel and information" 


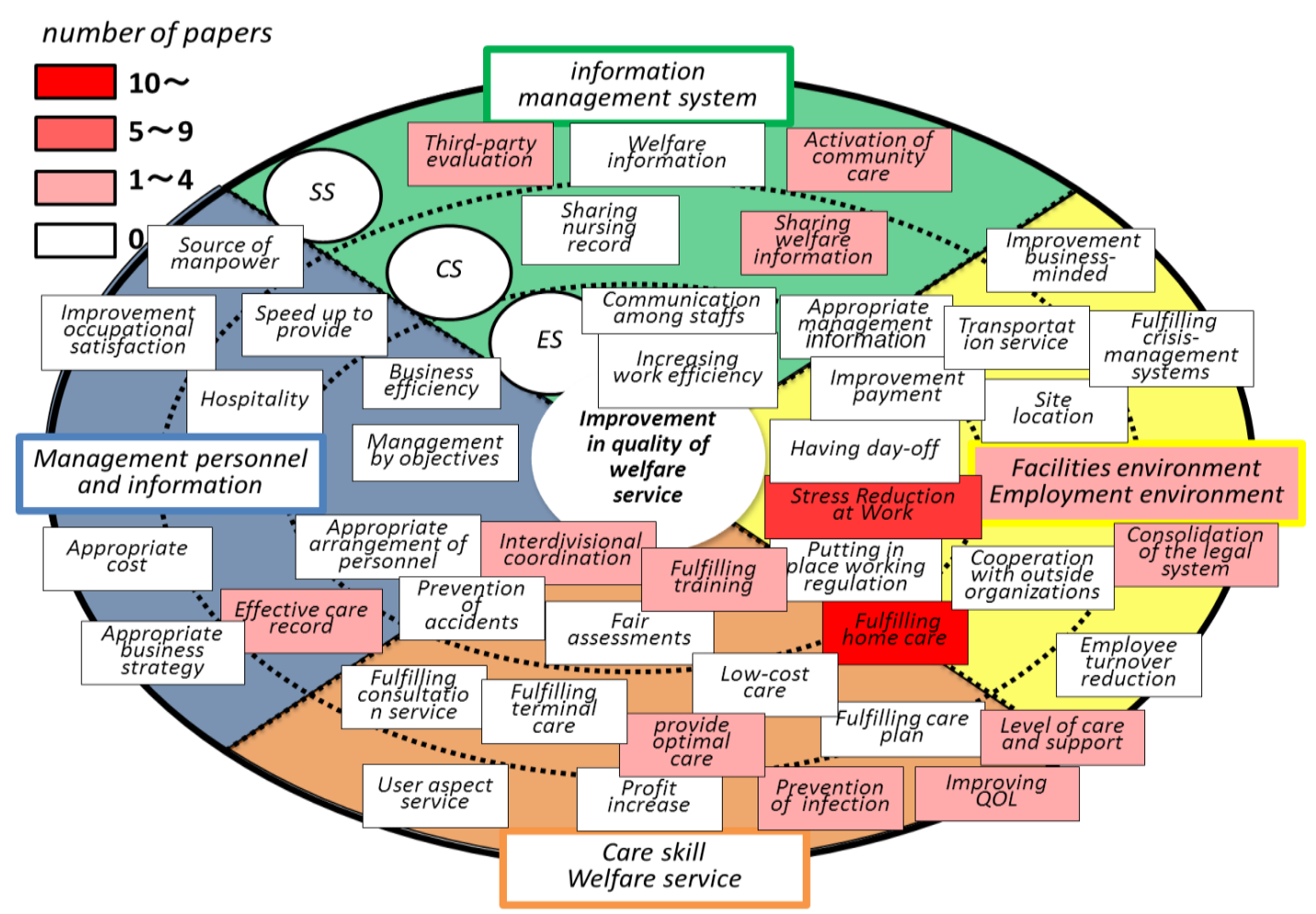

Figure 6. Matrix with components improving quality of welfare service

Papers related to "relief of job strain" and "fulfilling home care" were the most common. As for stress reduction at work, I think that it may be necessary to make a manual for human resource development that includes a discussion of mental health skills for individuals. In Japan, there was report about Development manual of stress prevention for accident prevention by Otsuka, 2010. Moreover, Ministry of Health, Labour and Welfare worked out guideline about Provision of mental health at work. It is quite possible that such a manual will be used for education in general settings in the future. Please make sure to include examples of these papers.

Next, we can see the least number of kinds of researches. "Dimension of management personnel and information" and "Dimension of Information management systems" were the least studied topics in original papers. It is necessary to have a firm grasp of management personnel and information to implement TQM successfully in the welfare industry. With regard to information management systems, despite brief mention in research on information storage, there are no original papers describing a concrete system. However, we predict that increasing numbers of facilities will implement electronic health record systems or ordering systems because the $50 \%$ of the total papers had some mention of information storage.

So, it is thought to be done research in future as follows.

First, in this paper, we examine the trend in research on the quality of service provided in the welfare industry. However, the trend is not directly related to the quality of service in the original paper. All researches take a partial view as themes for improving quality and have a short-term consequence. We expect that the form of welfare work will be reviewed, and the approach to the quality improvement of each original facility's service will be extended.

Second, the current study was limited because it relied on results from Google Scholar and Cinii only. Although, few general academic concerns stood out in relief, a paper search system targeted to a specialized field would be expected to lead to more detailed results. Furthermore, we found that the paper searching systems used in our study have two problems. One problem is that operational expressions are not read correctly by the system. The 
other is that the field of paper and numbers differ according to site. Therefore, these search sites require additional work with respect to their search functions, and work must be done to ensure that more science publications are registered with these sites.

\section{CONCLUSION}

In Japan, the enforcement of the Long-term Care Insurance Act in 2000 called special attention to the quality of service provided in elder care facilities. However, this involves several problems, one of which is that there is a lack of sufficient scientific validation in papers about the quality of service in elder care facilities. This study is aimed at carrying out a systematic scientific review of papers examining the quality of service in elder care facilities in Japan.

The results suggested by a scientific review of papers is that the quality of service is not examined in total judging from the original papers extracted during a particular period of searching.

As regards the tendency of the researches, there were many researches on the facilities staff using the questionnaire survey and about $80 \%$ of the object focused on the staff aspect.

Moreover, we expect that the facilities that will introduce information systems in the future will increase, because $50 \%$ of researches focused on information. The researches that examine the quality of service overall in the welfare industry will increase, and business manuals, a system for the development of a manual of human resources development, and a system for intelligence sharing on the welfare front will be efficiently implemented in the future. We expect that the form of welfare work will be reviewed, and the approach to the quality improvement of each original facility's service will be extended.

The challenge of the study lay in using only Google Scholar and Cinii, which are paper searching systems and index sites in an integrated field. Although, few general academic concerns stood out in relief, a paper searching system for the specialized field would be expected to lead to more detailed results.

Furthermore, we found that the paper searching system have two problems. One problem is that the operational expression cannot be correctly read. The other is that the field of the paper and the numbers are different according to the site.

Therefore, additional work is required for these search sites with respect to their search function and ensure that more science publications are registered.

\section{AUTHOR INFORMATION}

Ayako Oura is a graduate student of Department of Health and Welfare Sciences, Graduate School of Human Science at Waseda University, Japan. She majored in management engineering in the general areas in BA. Her current research interest is an applied study of quality management in hospital and welfare facility with biological survey. E-mail: ayako_oura@yahoo.co.jp. Corresponding author.

Manabu Yamaji is a researcher in Advanced Research Center for Human Sciences at Waseda University, Japan. He received his Master of Engineering degree in Graduate School of Information Systems at University of ElectroCommunications in 1999. His current research and teaching interests are in the general area of quality management. In particular, he is interested in Total Quality Management, Computer Aided Engineering. E-mail: manabu.yamaji@gmail.com

Atsushi Ogihara is an associate professor of Department of Health Science and Social Welfare, Faculty of Human Sciences, Waseda University, Japan. He received the degree of Ph.D in Medical Science from Juntendo University of Japan and the Akino memorial research fellowship of the United Nations University. He has organized a quality management of welfare facilities research group to elucidate factors and process about quality of service in welfare facilities. E-mail: aogi@waseda.jp. 


\section{REFERENCES}

1. Health, Labour and Welfare Ministry, Population Survey Report, 2011.

2. Department of Health Service Management, International University of Health and Welfare, Beginning Business Administration of Medical and Welfare in Japanese, International University of Health and Welfare Press, 2004.

3. Health Care Research Institute, Care Administration White Paper in Japanese, Japan Medical Planning, 2010.

4. Health and Welfare Statistics Association, Journal of Health and Welfare Statistics, 57(11), 2010/2011.

5. National Institute of Informatics, Cinii, http://ci.nii.ac.jp/, 2011.

6. Google, Google Scholar, http://scholar.google.co.jp/, 2011.

7. Health, Labour and Welfare Ministry, Outline of the nursing insurance system (in Japanese), http://www.mhlw.go.jp/topics/kaigo/index_gaiyo.html

8. M. Yokoyama, A study on how care workers at nursing-homes write their care-records, Bulletin of the School of Nursing, Yamaguchi, 6, 87-93, 2000.

9. T. Yumi, Problems of Home Health Care and the Measures for It: Based on Fact-Finding Questionnaires, The journal of Juntendo Medical College of Nursing, 2, 30-40, 1991.

10. N. Eguchi, Relationship between the stressor developing from work and psychological stress response: a study of the staff at homes for the aged, Memoirs of Ashikaga Junior College, 17(1), 65-72, 1997.

11. N. Eguchi, Effects of Everyday Life Stress on the Degree of Satisfaction in the Nursing Profession, Memoirs of Ashikaga Junior College, 18(1), 103-108, 1998.

12. S. Iwamoto, Information and the elderly: How much do they understand?, Bulletin of the School of Nursing, Yamaguchi Prefectural University, 2, 13-21, 1998.

13. M. Ogata, M.Doi,A Survey on Subjective Symptoms of Fatigue : Complaints of Fatigue among Workers Engaged in Day and Night Shifts and the Effect of Taking a Nap, Kawasaki journal of medical welfare, 9(2), 155-161, 1999.

14. I. Takeda,QOL Evaluation Table and Approval of the elderly for Public Care Insurance, Kawasaki journal of medical welfare, 9(2), 169-176, 1999.

15. N. Eguchi, K. Ishiguro, M. Tomizawa, Key Points and Problems Associated with Home Nursing in Japan : A Comparison between the Community Activity for Home Care in the United States and the Activities of Home Nursing Stations for the Care of the Aged in Japan, Memoirs of Ashikaga Junior College, 19(1), 55-61, 1999.

16. T. Higashi, K. Uchiyama, T. Kusano, R. Nakamura, T. Ishida, Y. Tomita, The study of the Long Term Care Insurance by the questionnaire method for the caretakers, Bulletin of the School of Allied Medical Sciences, Nagasaki University, 13, 103-107, 1999.

17. S.Hirayama, Y.Kanemitsu, T. Shindo,The Relationship between the Mourning Process of Home Caregivers and Their Perceived Social Support, Kawasaki journal of medical welfare 9(1), 55-60, 1999.

18. H. Hashimoto,A Study of Advocacy Functions of Employees of Medical Welfare Institutions, Kawasaki journal of medical welfare, 10(1), 25-32, 2000.

19. F. Uchida, An Investigation on the Status of Patients in a Prolonged Vegetative State and their Caregivers in Okayama, Kawasaki journal of medical welfare, 10(2), 219-224, 2000.

20. H. Hitomi, Y. Nakamura, G. Osawa, S. Miyahara, C. Tokuyama, T. Ogawa, The Factor to Make the Palliative Care at Home of Elderly People Possible in Countryside, Kawasaki journal of medical welfare, 10(1), 87-95, 2000.

21. H. Mihara, M. Yokoyama, K. Minemoto,A research on perceptions about carework held by careworkers in nursing and residential home for the aged, Bulletin of the School of Nursing, Yamaguchi Prefectural University, 4, 20-25, 2000.

22. Y. Nakamura, S. Miyahara, H. Hitomi, T. Ogawa, Current State of Deaths at Home and Care in Cities and Problem of Social Welfare, Kawasaki journal of medical welfare, 10(2), 225-230, 2000.

23. H. Hiroe, G. Osawa, Y. Nakamura, T. Ogawa, K. Nakanishi, A. Ehara, The Relationship between Recovery from Grief and other Related Factors of Caregivers for the Aged, Kawasaki journal of medical welfare, 10(2), 273284, 2000.

24. H. Nagae, K. Naruse, H. Kawagoe, A structure of family support in home hospice care -Focusing on the support of the visiting nurse-,Bulletin of St. Luke's College of Nursing,26, 31-43, 2000.

25. K. Higuchi, A Family Member in Women to the Home Care: Care providers to The Ashikaga Nisseki Home Nursing Station, Memoirs of Ashikaga Junior College, 20(1), 73-81, 2000.

26. Y. Bessho, T. Hosoya, M. Hasegawa, Y. Yoshida, J. Kitade, R. Agata, A. Kawabata, Collaboration between home care nurse and physical therapist in the home care of bed-ridden elderly, Journal of Fukui Medical University, 1(3), 495-509, 2000. 
27. Y. Bessho, T. Hosoya, J. Kitade, R. Agata, A. Kawabata, Rehabilitation Programs Provided by Home Care Nurses for the Bed-ridden Elderly, Journal of Fukui Medical University, 1(1), 191-198, 2000.

28. K. Saeki, M. Miura, T. Kido, K. Tsukasaki, R. Kimura, The sense of married female teachers for taking caregiver's role for their elderly parents, Memoirs of School of Health Sciences Faculty of Medicine Kanazawa University, 24(2), 39-46, 2001.

29. T. Matsui, S. Okada, Differences in Assessment Perspectives between Nurses and Care Workers: Survey of Home-Based Care Center Staff, Bulletin of Osaka Prefectural College of Health Sciences, 6, 55-62, 2001.

30. Y. Lee, Interprofessional Co-operation in Community Welfare, Kawasaki journal of medical welfare, 11(2), 255260, 2001.

31. T. Tsukahara, S. Miyahara,A Study on Terminal Care at a Special Nursing Home for the Elderly, Kawasaki journal of medical welfare,11(1), 17-24, 2001.

32. K. Kunitake, H. Furukawa, F. Noguchi, Consciousness of Caregiver who Takes Care of the Elderly at Home, Journal of the faculty of nursing and nutrition Siebold university of Nagasaki, 1, 7-19, 2001.

33. M. Tsukada,S. Uno, M. Kamiyama, H. Kobayashi, Y. Tamura, E. Matsuda, Survey concerning adults receiving speech therapy at community-based health-care and social-welfare facilities, Higher brain function research, 21 (4), 236-241, 2001.

34. S. Miyahara, A Study on the Effectiveness of Assigning Regular Staff Physicians to a Special Nursing Homes for the Elderly, Kawasaki journal of medical welfare, 11(1), 9-15, 2001.

35. M. Segawa, Effect of Family System Care to Patient and Family in Home Nursing, Kawasaki journal of medical welfare, 11(2), 277-286, 2001.

36. Y. Sawada, Care, Gender, Burnout: The relationship between Care stress and Burnout of Care worker in nursing home, Kwansei Gakuin policy studies review, 1, 1-17, 2002.

37. M. Kono, K. Kuroda, The present situation and problems of the care-giving facilities for the elderly people, Bulletin of Aino Gakuin, 15, 79-87, 2002.

38. M. Washio, Y. Arai, H. Izumi, M. Mori, Burden on family caregivers of frail elderly persons one year after the introduction of public long term care insurance service in the Onga District, Fukuoka Prefecture evaluation with a Japanese version of the Zarit caregiver burden interview, Japanese journal of geriatrics, 40, 147-155, 2002.

39. T. Mahune, S. Ando, A. Sema, The Comparison between JAPAN and AUSTRALIA of The Community Care System for Olds: An Analysis of The Quality of Health and Health and Life for Main Caregivers, Co-Residence with Alzheimer's Disease, Niigata Medical Journal, 116(2), 78-89, 2002.

40. S. Shindo, Changes in Activities of Daily Living in a Special Nursing Home During a Five-year Period, Bulletin of College of Allied Medical Science Akita University, 10(2), 165-170, 2002.

41. A. Minematsu, Opinion Poll of Rehabilitation Given to Care Workers and Students: A Link of Consideration of Taking Their Job, Japanese journal of occupational medicine and traumatology, 51, 405-409, 2003.

42. H. Morimoto, A Study of Care Staff's Mental Health in Nursing Homes : To Think about Work Style in terms of Work Control, Kawasaki journal of medical welfare, 13(2), 262-269, 2003.

43. A. Kobayashi, M. Yajima, K. Umebayashi, K. Kobayashi, A. Ohno, The Quality Assessment of In-Home Services in a Community under the Long Term Insurance System: The Challenges to Support In-Home Services Users in small towns and villages, Gumma Paz Gakuen College, 5(1), 33-46, 2003.

44. K. Higuchi, Y. Dai, R. Wakasa, The Meaning of Study of the Home Nursing Practice: From Analysis of the Summarized Records of Home Visiting Nursing Practice, The Journal of Juntendo Medical College of Nursing, 14, 85-94, 2003.

45. T. Yamamoto, Y. Aoki, F. Kawabe, F, S. Takahashi, A. Nagata, Y. Wazumi, Necessary Knowledge Spread and Depth for Applying Nursing Methodology to Paper Patient, Journal of School of Nursing, Chiba University, 25, 45-51, 2003.

46. S. Hisano, H. Shimizu, Finding a physical environment desirable for elderly residential facilities: A survey of the literature, Journal of health sciences Hiroshima University, 3(1), 21-36, 2003.

47. S. Koike, Long-term care services for the elderly in municipalities before and after the introduction of Long-term Care Insurance, Journal of the Keio Medical Society, 81(4), 271-286, 2004.

48. S. Nitta, N. Mochizuki, Y. Shimizu, N. Uemura, Forms and Contents of Notebooks Utilized Between Elderly/families and Day-Service Providers, Yamanashi Nursing Journal, 4(1), 27-33, 2005.

49. N. Mochizuki, S. Nitta, Y. Shimizu, Effects of Psychoeducational Intervention on Burden in Family Caregivers of the Elderly Receiving Adult Daycare Service, Yamanashi Nursing Journal, 3(2), 27-32, 2005.

50. H. Otsu, S. Takayama, Y. Handa, C. Ogawa, S. Nomura, Wandering Behavior in Elderly People with Alzheimer's Disease, Humanity and science, journal of the Faculty of Health and Welfare, 6(1), 25-35, 2006. 
51. Y. Saito, M. Matsumoto, S. Ohta, T. Yoshinaga, Using Technical Aids to Improve the Seating Environment and Living Activities of Elderly Patients in Nursing Homes, Kawasaki journal of medical welfare, 15(2), 529537,2006.

52. M. Furuse, K. Saeki, The supporting process of visiting nurses in japan for facilitating the independence of family caregivers in caring for medical technology-dependent relatives, Journal of the Tsuruma Health Science Society Kanazawa University, 29(2), 55-64, 2006.

53. Y. Shinagawa, T. Kishimoto, S. Ohta, Analysis on Human Behavior of Elderly People Living Alone Focusing on Seasonal Variation, Kawasaki journal of medical welfare, 16(1), 121-128, 2006.

54. T. Nishikawa, What Choice do Type A Moderate Fee Senior Citizen Home have from now? : Study on the direction of "Tokutei institution" in Care Provision(The Present Situation and Problem of Moderate Fee Senior Citizen Home),Journal of the Socio-Cultural Research Institute, Ryukoku University, 8, 189-205,2006.

55. K. Matsumoto, A. Wakasaki, The Current State of Successful Aging in the Elderly, Kawasaki journal of medical, 6(1), 67-72, 2006.

56. Y. Futoyu, Y. Okada, T. Shinpou, M. Okuyama, K. Takeda, T. Kawaguchi, Preparing for a Regional Health Welfare System Supporting a Healthier Life Expectancy for Older Adults in the Chusankan Area, Kawasaki journal of medical, 15(2), 423-431, 2006.

57. K. Takeda, Y. Futoyu, Conceptual Structure of Spirituality in Elderly Japanese, Kawasaki journal of medical, 16(1), 53-66, 2006.

58. S. Moochizuki, H. Yamagishi, S. Iijima, S, The Recognition of Community Public Health Nurses in Ongoing Education for Newcomers, Yamanashi Nursing Journal, 5(2), 19-24, 2007.

59. K. Suhiura, M. Ito, H. Mikami, Family caregiver burden caused by behavioral and psychological symptoms of dementia: Measurement with a new original scale, Japanese journal of geriatrics, 44(6), 717-725, 2007.

60. N. Ichiki, Public responsibility of cities, towns, and villages in nursing care for elderly people security: Responsibility that cities, towns, and villages that centered on nursing care insurance system should accomplish (Humanities and Social Sciences), Bulletin of Kyushu women's university, 43(3), 1-20, 2007.

61. M. Ozawa, M. Mizuno, E. Sato, T. Takaya, H. Masaki, C. Hirose, K. Takeo, Study on Improving the Clinical Training for New Graduates from Nursing Schools, J Nurs Studies N C N J, 6 (1), 3-9, 2007.

62. H. Igarashi, Behavior of Infection Control of Caregivers in Support for Daily Life of Home Medical Care, Yamanashi Nursing Journal, 6(2), 25-30, 2008.

63. J. Nakanishi, M. Morishita, Awareness of the Roles of Nurses in Regional Collaboration, and Their Motivation and Self-Efficacy, Bulletin of Nagasaki University School of Health Sciences, 20(2), 9-18, 2008.

64. S. Mochizuki, M. Mogi, S. Iijima, An Approach to Work Satisfaction and Burnout among Visiting Nurses in A Prefecture in Japan, Yamanashi Nursing Journal, 8(1), 9-14, 2009.

65. N. Takayama, K. Takeo, Structure of Teamwork and Relevant Factors in Nursing Activities, J Nurs Studies $N C$ $N J, 8(1), 1-9,2009$.

66. N. Watanabe, Comparison of welfare worker and student attitudes on person-centered welfare services, Tokiwa Journal of Human Science, 17, 19-28, 2009.

67. S. Kemuyama, Recognition of depression state in dementia by care workers and nurses and problems encountered, Bulletin of Graduate School of Health Sciences, Akita University, 17(2), 1-11, 2009.

68. M. Fukuma, K. Shiwaku, Changes of Care Levels of Frail Elderly Individuals After Introduction of Long-Term Nursing Care Insurance System, Journal of the Japanese Association of Rural Medicine, 58 (5), 516-525, 2010.

69. K. Mitoku, Prevalence of smoking among workers at geriatric facilities and the relationship between smoking and their occupation-related stress, Japanese Journal of Tobacco Control, 5(1), 10-17, 2010. 